\title{
THE GRAMMATICALIZATION OF TEMPORAL SUBORDINATING CONJUNCTIONS IN SURGUT OSTYAK
}

\author{
KATALIN GUGÁN
}

\begin{abstract}
This paper investigates two subordinating conjunctions of the Surgut dialect, one of the Eastern dialects of Ostyak. One of these, kuntə 'when, if' acquired the function of a conditional conjunction in addition to its ancient function of a temporal question word; a special feature of its grammaticalization is that whereas it occurs clause initially as a question word, in its conditional function it occurs clause finally. The other item investigated, $k \breve{u} \breve{c}$, may have four different functions in this dialect: it can serve as (a) a temporal conjunction expressing contact anteriority, 'as soon as'; (b) a conjunction of concession, 'although'; (c) a paired concessive-disjunctive conjunction, 'whether... or'; and (d) the anterior constituent of various compounds in 'any-' (e.g., 'anyone'). Its origin is debated: it is either a Russian loanword or else an Ob-Ugrian innovation. This paper argues that, in view of the results of research on grammaticalization in general, the former claim can be discarded with a high degree of probability. Finally, the paper investigates the debated issue of whether these items can be regarded as conjunctions proper and concludes that nothing warrants their exclusion from that category.
\end{abstract}

In addition to an earlier form of subordination involving a non-finite verb form and no conjunction (and one that is consistent with the basic SOV word order), subordinate clauses involving conjunctions and finite verb forms constitute a more recent phenomenon in the various Ostyak dialects. ${ }^{1}$ Studies of primary and secondary grammaticalization with respect to conjunctions - i.e., the investigation of what types of lexical items tend to turn into conjunctions and what novel functions the conjunctions already in existence tend to develop, respectively - are both widespread. The subject-matter of the present paper will be two linguistic items that are usually classified as subordinating conjunctions and

${ }^{1}$ It is impossible to tell exactly when subordination involving a conjunction first appeared in the language but certain conclusions can be drawn from early text collections. Looking at Southern Ostyak texts, Csepregi (1996) claims that around the turn of the century (i.e., around 1900) subordination with non-finite verb forms still prevailed but some finite subordinate clauses had already occurred. 
that can definitely be brought into connection with temporal reference but have developed other functions, too, hence the changes involving them mainly belong to the area of secondary grammaticalization. Their semantic characteristics will be reviewed first, followed by a summary of their syntactic properties. ${ }^{2}$

One of these items is kunta, having two distinct functions: an interrogative pronoun meaning 'when' as in (1), and a subordinating conjunction meaning 'if' as in (2):

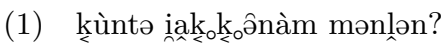

when home go.prs.2sg

'When do you go home?'

(Paasonen-Vértes 2001, 24/6)

(2) os t'enə əntə ăwtat

kุuntə, шеліләш tŏrəma păwat.

also thus not cut.prt.pass.3pl if reindeer.Px.pl.1pl sky.lat freeze.prt.pass.3pl 'If we had not driven them inside, they would have got frozen.'

(Csepregi 1998, 62/4)

Which of the two functions is the earlier one is not at issue: the interrogative pronoun goes back to the Proto-Uralic pronominal stem $\mathrm{ku}$ $\sim$ ko- (Rédei 1986-1988, 191). It can be observed in general that languages often employ interrogative pronouns as conjunctions in order to express subordination (Harris-Campbell 1995, 293-8). Semantic changes that conjunctions tend to undergo, including the development of their additional functions, can be traced back to pragmatic factors: certain conversational implicatures that are frequently associated with sets of clauses linked by the given conjunction get semanticized during language use and become permanent components of its meaning (Hopper-Traugott 1993, 72-7). One of these implications is that of two events occurring in a temporal sequence the earlier event may be a condition for the later event: the conventionalization of the implication is reflected by conditional conjunctions developing from temporal ones.

The derivation of the semantic change of the other conjunction we look at in this paper, $k \breve{u} \breve{c}$, is more problematic. Four different functions

\footnotetext{
2 This paper is based on data coming from the following sources: Paasonen-Vértes (2001), Honti (1978a;b), Honti-Rusvai (1977), Csepregi (1998). For the sake of philological accuracy, as well as in order to avoid mistakes that might crop in while the primary data are brought to a consistent format, linguistic data will be cited in terms of the authors' own transcription systems and with the authors' own translations (translated into English).
} 
of that item can be distinguished: contact anteriority, 'as soon as', as in (3); concession, 'although', as in (4); paired concessive-disjunctive use, 'whether... or', as in (5); and particle-like use, 'any-', as in (6):

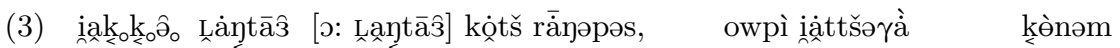
in step.inf as begin.prt.3sg door middle.translat dig.partperf

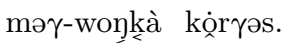
earth-pit.lat fall.prt.3sg

'As he began to enter, he fell into the earth-pit dug in the middle of the doorway.'

(Paasonen-Vértes 2001, 96/1)

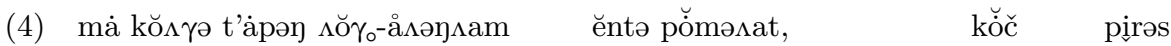
my yet rotten bone-end.Px.pl.1sg not catch.fire.pass.prs.3sg although old ko wăsəm.

man be.prs.1sg

'My old bones have not yet burnt up, although I am old.' (Honti 1978b, 128/4)

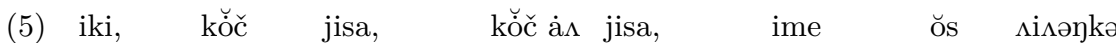
old.man whether cry.imp.2sg or not cry.imp.2sg wife.Px2sg again alive.translat ĕntə jĕ

not become.prs.3sg

'Old man, whether you cry or not, your wife will not come to life.'

(Honti-Rusvai 1977, 225/6)

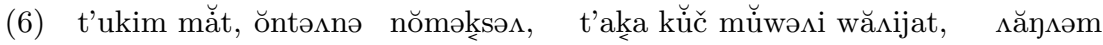
so tired in.herself think.prs.3sg well any thing be.imp.3sg step.prs.1sg panə t'etti jăǩ

and thus in

"She was so tired that she said to herself: "Whoever should be in there, I will enter.",

(Csepregi 1998, 74/2)

Some authors (including Munkácsi 1894, 216; Kálmán 1961, 182; Steinitz $1966,588)$ trace this item back to the Russian conjunction xomb, dialectal xowb 'albeit, though; whether... or' whose cognates can be found, in addition to Ostyak dialects, also in Vogul. (In an earlier paper, Gert Sauer also subscribes to that view, cf. Sauer 1993, 355.)

However, Csepregi (1996) calls the reader's attention to the problematic nature of that derivation. In the Southern Ostyak texts she studied, two kinds of forms are attested: a conjunction küš 'as soon as' (also occurring as an anterior constituent in Kr. Sav. ${ }^{3}$ küšpa 'if only') on the one

${ }^{3}$ Abbreviations: Kr.: Krasnojarsk dialect, Sav.: Savodnija dialect, Vj.: Vasjugan dialect. 


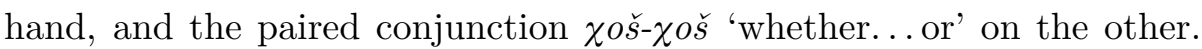
She does not reject derivation from the Russian conjunction mentioned in the case of either, but she claims that the former must be an earlier borrowing, in view of its subsequent phonological and semantic changes,

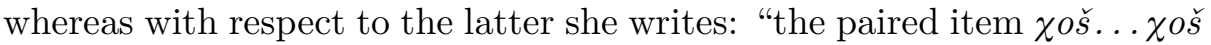
is a truncation of the Russian verb хочешь 'you want' and as such it is related to the conjunction $k \ddot{u}$, but appears to be a much later borrowing" (Csepregi op.cit., 62). Gert Sauer, too, presents a rather altered view in his recent paper (1999): he says that the item at hand is not a loanword but an internal development going back to an Ob-Ugrian origin. Although the functions of Russian xomb and Ostyak kö̌c largely overlap, this is due to mere chance in his opinion, given that the Ostyak wordunlike the Russian one - has a temporal meaning, too. The syntactic behaviour (word order) of the Ostyak conjunction, too, differs from that of the Russian word; if it were a case of borrowing, the syntactic pattern of the source language would have to be copied as well. Furthermore, he claims, phonological factors also disprove the Russian origin of the word. He adds, however, that certain occurrences of the given item may be influenced by the Russian conjunction of similar form and meaning (e.g., wherever its word order is of the Russian type), and that in certain dialects one can observe a homonymous but borrowed item as an anterior constituent: Vj. kös'-koji 'anyone'.

As can be seen, then, three kinds of explanations exist with respect to the origin and functions of Ostyak k $\breve{u} \check{c}$ : (a) Russian borrowing (in all roles); (b) multiple/multi-stage borrowing (in view of the differences); and (c) an internal development that occasionally may follow a borrowed syntactic pattern and has a homonymous borrowed counterpart.

In this case, we can rely on the results of general research on grammaticalization, ${ }^{4}$ in particular, those concerning grammaticalization continua that are characteristically taken to be unidirectional. Such a continuum is the range of semantic changes of conjunctions (Hopper-Traugott 1993, 178): temporal > conditional (or causal) > concessive. It is definitely to be taken into consideration that, were we to reckon with borrowing from Russian, we would be forced to derive the temporal meaning from the concessive one, contrary to the strong tendency of the direction of semantic change referred to. (Since Russian xomb can be traced

${ }^{4}$ Dér (2002) employs a similar method when she discusses the history of a Hungarian suffix of debated origin and takes a stance on that issue on the basis of general statements of grammaticalization research. 
back to the grammaticalization of a participial form of xomemb (Vasmer 1958, 268), the idea that the two Ob-Ugrian languages might have borrowed an earlier, temporal meaning, can be excluded.)

Returning to the above grammaticalization continuum, its discrete staging is necessarily arbitrary since it does not allow for transitional phases that are exactly the periods in which the added pragmatic meaning referred to above becomes a component of the meaning of the given conjunction. And in view of the fact that such changes are usually not "supplantive" but additive, and hence the phenomenon of layering also occurs, it is to be expected that intermediate domains of the continuum will be possible to attest, too: that examples can be found to fall between the assumed initial stage, the purely temporal relation as in (7) and the assumed final stage as in (8). The latter example also shows that the conjunction can have a concessive meaning in positions other than clause initially:

(7) kem kŭč $\Lambda$ 'iwət $\Lambda ә n$, ma t'i jŏwətıəm.

out as go.prs.2sg I behold come.prs.1sg

'As soon as you get out, I will come then.'

(Csepregi 1998, 82/3)

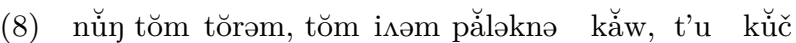

you that sky that front side.iness stone that though

powse, muүti wičəpə әntə pitəs.

blow.prs.3sg.sgobj through never get.prs.3sg

'On the other side of the world, there is a stone. No matter how strongly you blow it, you will never go through it.'

(ibid., 64/3)

This latter example may also serve as an instance of the implication involved in concession, as follows (where $\mathrm{S}_{1}$ and $\mathrm{S}_{2}$ are clauses): "With a sentence of the form bár $S_{1}$, mégis $S_{2}$ 'although $\mathrm{S}_{1}$, nevertheless $\mathrm{S}_{2}$ ', the speaker states ' $\mathrm{S} 1$ and $\mathrm{S}_{2}$ ' and (s)he pragmatically presupposes or believes that 'given $\mathrm{S}_{1}$, it could not/should not be the case that $\mathrm{S}_{2}$ '" (Bánréti 1983, 10). In the above example, the statement is that the wind blows the stone and cannot go through it; the presupposition is: if it blows the stone (strong enough), it should be able to go through it. Concession, then, is bound up with conditionality, opposition, and causality; in the case of the conjunction at hand, that implication has turned into part of the meaning of an originally purely temporal item.

In the texts we have studied, quite a number of examples involve this conjunction linking clauses that are, beyond temporal relations, in a 
semantic relationship with one another that is not quite concession but has something to do with the neighbouring categories of conditionality, opposition, or causality. In these cases, it is context that is more or less responsible for such additional meaning.

(9) kem kŭč $\Lambda$ 'iwət, kemən pətə $\gamma \Lambda$ em.

out as go.prt.3sg outside dark

'As he goes out (he sees that) it is dark outside.'

(Csepregi 1998, 84/7)

Context: "In the house, it is broad daylight. What could have happened, he thinks. Has the sun risen? He leaves the house."

Potential presupposition: If it is light inside, it should be light outside, too.

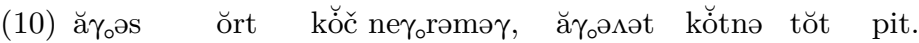

Chukchee leader as jump.prt.3sg sledge.pl middle there fall.prt.3sg

'The Chukchee leader jumped, and he fell between the sledges in the middle.'

(Honti 1978b, 135/1)

Context (broader): The leader is bragging; earlier he has proven that he is good at jumping. It is an unexpected consequence that he now nevertheless falls down.

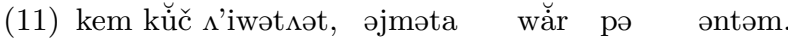

out as run.prs.3pl something thing in.fact is.not

'As they run out, there's nothing outside.'

(Csepregi 1998, 82/3)

Context: "Suddenly some loud noise is heard, the earth begins to tremble all around. [...] The people all run out, but you should not."

Potential presupposition: If there is some noise outside, something must have caused it.

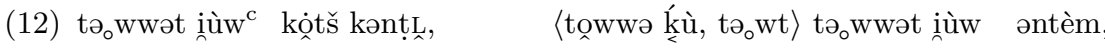

fire wood as search.prs.3sg fire wood is.not

'As he is looking for firewood, firewood there is none.'

(Paasonen-Vértes 2001, 68/2)

The last example, in which there is clear contradiction between the two clauses, minimally differs from the next one, exhibiting a purely concessive relation:

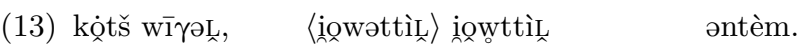
as call.prs.3sg
come.partimp. $3 \mathrm{pl}$ is.not

'Even though he calls, there's no one coming.' (Paasonen-Vértes 2001, 22/5)

It could be expected that causal relations should be linked to temporal relations with a higher probability (concession being in general a very 
complex logical relation that is normally grammaticalized rather later; Hopper-Traugott 1993, 178), yet in these texts there are only two pairs of clauses (both occurring in the same tale and being almost identical) in which the event expressed in one of them follows from the event expressed in the other, rather than contradicting the other clause or the context:

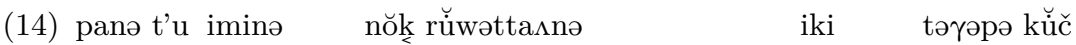

and the woman.loc up confuse.partimp.Px3sg.loc old.man here as

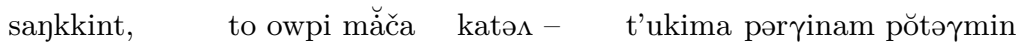

wake.up.prt3sg ? door-post.lat grab.prt3sg such.lat back draw.advpart

jər.

become.prt.3sg

'And as the old woman tried to wake him, the old man woke up, he grabbed at the door-post, so much did he withdraw.'

(Csepregi 1998, 94/25)

(As the giant woke up, the boy grabbed at the door-post because he was so frightened.)

As can be seen, then, the Surgut dialect data widely reflect not only the initial and final phases of the assumed functional expansion of the conjunction but also its transitional phases. Hence I think that, wherever the temporal, concessive, or transitional conjunction occurs in a preverbal position, it is unjustified to take it to be of a Russian origin; rather, internal development can be assumed and indeed demonstrated. Word order cannot be taken as decisive in the dialect under scrutiny anyway: with few exceptions, concessive $k \breve{u} \breve{c}$ also occurs in a preverbal position

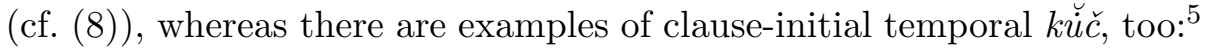

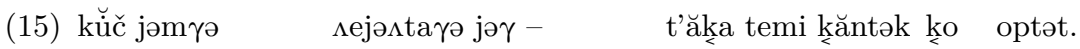

as good.translat watch.inf begin.prt.3sg well this Ostyak man hair.pl

'As he looks at it closer: well, it is human hair.'

(ibid., 92/22)

Since in the dialect under investigation there is no phonological distinction between anterior constituent-like or paired ('whether... or') and temporal-concessive $k \breve{u} \check{c}$, we cannot take a stand as to whether this is the result of internal development or $k \breve{u} \check{c}$ follows the Russian pattern in this function - neither possibility can be excluded.

${ }^{5}$ Also, we are cautioned by the fact that word order variability in Ostyak in general and the Surgut dialect in particular is far from clearly understood, hence it is hardly possible to decide whether the cases at hand are those of the Russian pattern being copied or the conjunction raises from its preverbal position due to stress reasons. 
While so far the subject-matter of our investigation was the meaning or the semantic extension of the two conjunctions, in what follows, we will turn to their grammatical behaviour. In particular, we will ask if these items can be seen as subordinating conjunctions. Traditionally they are classified as such; but Sauer (1999) and Hartung (1999, 165-70) argue that this classification is the wrong one. Hartung has the following reasons not to take Ostyak clause-linking items to be conjunctions (and to call them junctors instead):

- conjunctions in general introduce clauses, whereas the items at hand do not: many of them go back to particles and continue to function as particles, too; they often occur after the focused word;

- conjunctions in general cannot be suffixed but some of the Ostyak ones can (those that go back to interrogative or deictic pronouns);

- some of them can take postpositions or possessive suffixes, especially those linking items that occur within subordinate constructions, in complement or relative clauses.

She also notes that, in Ostyak, coordination and subordination cannot be clearly told apart: only clauses whose conjunction is of a pronominal origin are undoubtedly subordinate ones. From this, and from the foregoing, it follows that in her view it would be difficult to define unambiguously which linking items qualify as conjunctions, even though on the basis of such a definition setting up the broader category of junctors could be avoided.

With respect to the two items that are investigated in this paper, only the first of the above criteria is applicable since they cannot be suffixed. Indeed, $k \breve{u} \check{c} \check{\text { most }}$ often is in a position within the clause (immediately before the verb, as in (1), (3), (8), (10), (12); if there is a preverb, then between the preverb and the verb, cf. (7), (9), (11)) where otherwise only particles occur. As a conditional conjunction, kuntz normally occurs clause finally, ${ }^{6}$ whereas the interrogative pronoun from which it developed into a conditional conjunction, just like other interrogative pronouns that are also used as relative pronouns, are clause initial. (In the texts under survey, no instance can be found of kzunta as a temporal conjunction occurring clause initially.) What it shows parallel word order behaviour with is the synonymous conditional construction involving a particle: the particle $k a$ also occurs at the end of its own clause, but whereas the latter

${ }^{6}$ There is a single attested example in which it occurs immediately before the verb. 
occurs in a clause containing a person-marked present participle, kuntz appears in finite clauses.

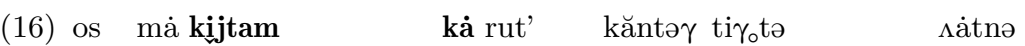

also I leave.partimp.1sg if Russian Ostyak appear.partimp time.iness

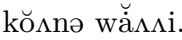

how kill.pass.prs.3sg

'If he leaves me, how do people kill him when they appear?' (Honti 1978b, 128/7)

Temporal relations are often expressed by person-marked participle + postposition constructions:

(17) jăkə jŏwətta $\quad$ atnə t'i čemotinən tăm, ăıintta

home get.partimp.2sg time.iness this suitcase.Px2sg there lie.down.partimp.2sg

natnə tŏw ăsəm u^yəna imte.

time.iness there pillow edge.Px2sg.lat put.imp2sg

'When you go home, put your suitcase beside your pillow at bedtime.'

(Csepregi 1998, 80/12)

It is imaginable then that the word order position of the conditional conjunction has been fixed at the end of the clause on the model of the position of conditional particles or of postpositions. Thus the word order of our two items does not indeed follow the "expected" conjunction pattern but one of them takes the position of particles, the other takes that of postpositions, whereas the rest of pronoun-based conjunctions occur clause initially. However, position in itself cannot play a decisive role: the two edges of clauses are in fact designated positions for conjunctions but this is not an absolute universal. The grammatical status of the two items at hand can be approached from two different angles: from the relation between the clauses they conjoin, and from the part of speech status of the two words. That is, it has to be demonstrated that the items at hand are conjunctions (rather than particles) and that the clauses they connect are related by subordination (or if they are not, what kind of relation there is between the two clauses).

To draw a distinction between conjunctions and particles is not unproblematic since they do not unambiguously differ either morphologically or syntactically (both parts of speech can be characterized by the following properties: they have no role as sentence constituents, they cannot be modified, they cannot be asked questions about, they do not enter into syntactic relationships with other words in the clause, and 
they cannot be suffixed; Keszler 2000, 268-81). Thus it is their functions alone ("whether their role is primarily linking or particle-like [modal, estimating, topic-enhancing]", ibid., 280) that can be used to tell them apart. Since other clauses containing particles are stand-alone sentences, whereas those containing the items discussed here require another clause to cooccur with, we should rather say their function is linking:

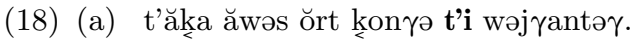

'And the Nenets leader withdrew.' (perfecivising particle)

(Csepregi 1998, 96/4)

(b) *kem kư̌č $\Lambda$ 'iwət $\Lambda$ ət

'As he ran out...'

The other criterion we mentioned is whether these linking items signal subordination or coordination, although these are not necessarily two distinct categories, either. According to traditional grammatical descriptions, coordination differs from subordination in that coordinated clauses are merely connected by some logical relation, some relation of content. By contrast, a subordinate clause is typically a clausal expression of some constituent of the main clause (Keszler op.cit., 472, 531). But there is a transitional range of clauses with a specific semantic content, one subtype of which involves types that are partly detached from their role of expressing some constituent of the main clause. Within this latter category, concession is the type that is the most independent of the main clause (ibid., 520).

Generative classification is based on the interchangeability of clauses: in coordination, the conjunction does not belong to either clause, hence the clauses are interchangeable if the conjunction is left where it is (between the two clauses) but not if it moves along with the second clause. By contrast, in subordination, the conjunction is part of the subordinate clause, hence it can move along with its clause but it cannot be left behind by moving the clause without it. However, this test does not apply in all cases: there are pairs of clauses in a concessive relation in which the conjunction is within the second clause, and conversely, not all subordinate clauses can in fact be moved. Another possibility of drawing a distinction is the investigation of binding relations of noun phrases in the clauses. This method also yields a transitional category: 'independent subordination' belongs to subordination on the basis of movability, but the distribution of binding relations is neither that of subordination nor that of coordination: it is a third type (Kenesei 1992, 537-52). 
Finally, a third type of classification (Hopper-Traugott 1993, 163-75) tells the kinds of relationships between clauses apart on the basis of their degree of grammaticalization; this method gives us three classes to begin with. 'Parataxis' is the kind of connection where it is only intonation or - in cases of a higher degree of grammaticalization - a conjunction that links the two clauses. The individual clauses are independent 'nuclei'. In 'hypotaxis', the dependence between the two clauses (the 'nucleus' and the 'margin') is mutual. This kind can be recognized, e.g., by all verbal categories being represented in the nucleus only. The relative independence of the margin, however, is shown by the fact that it may have its own illocutionary force, e.g., its own modality. Finally, in subordination, the clauses cannot have different illocutionary forces, the subordinate clause is equivalent to a constituent of the main clause, and the clauses are conjoined in some way. Taking all three systems of classification into account, then, the following discriminative criteria can be taken into consideration:

1. constituent role or logical relation,

2. interchangeability,

3. binding relations,

4. illocutionary force, and

5. downgradedness, nucleus/margin relationship.

The first of these (as well as the fifth criterion that is rather close to the first) tells us that the clauses under inspection belong to subordination (temporal clause) or to the intermediate range (conditionality, concession, either built on a constituent role or independent of it). Looking at the order of clauses, it appears that in an overwhelming majority of cases the clauses containing the conjunctions at hand are in initial position, but the inverse order is also attested for both conjunctions, hence the clauses are in principle interchangeable:

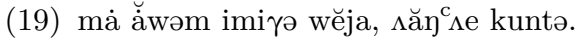

'Marry my daughter, if you love her.'

(Honti-Rusvai 1977, 225/5)

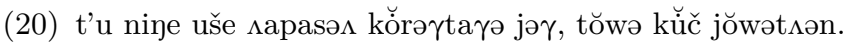

'The storehouse of your wife will have all but collapsed by the time you get there.'

(Csepregi 1998, 94/25) 
The interchangeability of the clauses would be characteristic of subordination; but the rarity of the available examples and their loose 'afterthought' character requires some caution here.

The investigation of binding relations and of whether the two clauses can or cannot have different illocutionary forces would both be very important - but these cannot be studied on a closed corpus, the task would require access to the competence of a native speaker. Finally, the criterion of downgradedness leads us back to the issue of function. The clauses containing the conjunctions under scrutiny here involve finite verb forms, yet they require complementation, a fact that - at least in pairs of clauses in a temporal relationship - may be connected to the aspect of the clause whose temporal structure is completed by that of an event expressed in another clause. All in all, it is highly doubtful whether setting up a novel part of speech category is justified, given that the two items studied here can be described in terms of existing categories and their properties.

Taking all the foregoing into consideration, we wish to conclude this paper by saying that, on the basis of their behaviour, both $k \breve{u} \check{c}$ and kunto are to be regarded as items grammaticalized into conjunctions; as well as that - in view of the fact that the development of concessive meaning into temporal meaning is made rather unlikely by conclusions drawn from the general theory of grammaticalization - the derivation of Surgut Ostyak $k \breve{u} \check{c}$ from Russian can probably be discarded. On the same account, it is expedient to regard the temporal meaning as primary within Ostyak, too. In its temporal function, this item is part of a system containing numerous synonymous possibilities, as the temporal relationship between two propositions can be expressed in several ways: by a non-finite verb form + personal suffix + postposition, by a non-finite verb form + personal suffix + case marker, or by a non-finite verb form + personal suffix on its own. Concession can easily be derived from a temporal meaning, and complex examples also abound.

Conditionality can also be expressed by synonymous constructions in addition to the conjunction kzuntə, for instance, by a present participle + personal suffix + particle complex as referred to above. At the same time, we do not have attested instances of this conjunction introducing temporal subordination (or any other kind of subordination) clause initially, whereas clause finally it has a characteristically conditional meaning; it appears that this word order pattern is a peculiarity of its grammaticalization. 


\section{References}

Bánréti, Zoltán 1983. A megengedő kötőszók szintaxisáról és szemantikájáról [On the syntax and semantics of conjunctions of concession] (Nyelvtudományi Értekezések 117). Akadémiai Kiadó, Budapest.

Csepregi, Márta 1996. Orosz nyelvi hatás a déli osztják szintaxisban [Russian influence in Southern Ostyak syntax]. In: Edit Mészáros (ed.): Ünnepi könyv Mikola Tibor tiszteletére [Festschrift for Tibor Mikola], 60-7. József Attila Tudományegyetem, Szeged.

Csepregi, Márta 1998. Szurguti osztják chrestomathia [A Surgut Ostyak reader]. Studia uralo-altaica supplementa. József Attila Tudományegyetem, Szeged.

Dér, Csilla Ilona 2002. Bemerkungen zur Grammatikalisierung als Erscheinung des Sprachwandels. In: Acta Linguistica Hungarica 49:149-78.

Harris, Alice C. - Lyle Campbell 1995. Historical syntax in cross-linguistic perspective. Cambridge University Press, Cambridge.

Hartung, Liselotte 1999. Zur Entwicklung des chantischen Konjunktionalsystems. In: Hasselblatt - Jääsalmi-Krüger (1999, 165-70).

Hasselblatt, Cornelius - Paula Jääsalmi-Krüger (eds) 1999. Europa et Sibiria: Beiträge zu Sprache und Kultur der kleineren finnougrischen, samojedischen und paläosibirischen Völker. Gedankband für Wolfgang Veenker. Otto Harrassowitz, Wiesbaden.

Honti, László 1978a. Szurguti osztják szójegyzék [A Surgut Ostyak word list]. In: Nyelvtudományi Közlemények $80: 327-45$.

Honti, László 1978b. Tromagáni osztják szövegek [Tromagan Ostyak texts]. In: Nyelvtudományi Közlemények 80 : 127-39.

Honti, László - Julianna Rusvai 1977. Pimi osztják szövegek [Pim Ostyak texts]. In: Nyelvtudományi Közlemények 79 : 223-32.

Hopper, Paul J.-Elisabeth Closs Traugott 1993. Grammaticalization. Cambridge University Press, Cambridge.

Kálmán, Béla 1961. Die russischen Lehnwörter im Wogulischen. Akadémiai Kiadó, Budapest.

Kenesei, István 1992. Az alárendelt mondatok szerkezete [The structure of subordinate clauses]. In: Ferenc Kiefer (ed.): Strukturális magyar nyelvtan 1. Mondattan [A structural grammar of Hungarian 1. Syntax], 531-713. Akadémiai Kiadó, Budapest.

Keszler, Borbála (ed.) 2000. Magyar grammatika [Hungarian grammar]. Budapest, Nemzeti Tankönyvkiadó.

Munkácsi, Bernát 1894. A vogul nyelvjárások szóragozásukban ismertetve [Suffixation in Vogul dialects] (Ugor füzetek 11). MTA, Budapest.

Paasonen, Heikki - Edith Vértes 2001. H. Paasonens surgutostjakische Textsammlungen am Jugan. Neu transkribiert, bearbeitet, übersetzt und mit Kommentaren versehen von Edith Vértes (MSFOu. 240). Suomalais-Ugrilainen Seura, Helsinki.

Rédei, Károly (ed.) 1986-1988. Uralisches Etymologisches Wörterbuch. Akadémiai Kiadó \& Otto Harrassowitz, Budapest \& Wiesbaden. 
Sauer, Gert 1993. Zur Abgrenzung der russischen und tatarischen Lehnwörter in den obugrischen Sprachen. In: Marianne Sz. Bakró-Nagy-Enikő Szíj (eds): Hajdú Péter 70 éves [Péter Hajdú is 70]. Linguistica Series A, Studia et Dissertationes 15, 353-8. MTA Nyelvtudományi Intézet, Budapest.

Sauer, Gert 1999. Ostjakisch köč - ein russisches Lehnwort? In: Hasselblatt-JääsalmiKrüger (1999, 387-90).

Steinitz, Wolfgang 1966. Dialektologisches und etymologisches Wörterbuch der ostjakischen Sprache. Akademie Verlag, Berlin.

Vasmer, Max 1958. Russisches etymologisches Wörterbuch. Carl Winter Universitätsverlag, Heidelberg.

Address of the author: Katalin Gugán

Research Institute for Linguistics

Hungarian Academy of Sciences

Benczúr utca 33.

H-1068 Budapest

Hungary

gugan@nytud.hu

A preliminary version of this paper was presented at the 2003 session of the Budapest Uralic Workshop organised by the Department of Finno-Ugristics of the Research Institute for Linguistics of the Hungarian Academy of Sciences. 